\title{
Modeling the Effect of Thermal Diffusion Process from Nuclear Power Plants in Vietnam
}

\author{
Tran H. Thai ${ }^{1}$, Doan Q. Tri ${ }^{2,3}$ \\ ${ }^{1}$ National Hydrometeorological Service, Hanoi City, Vietnam \\ ${ }^{2}$ International Association of Lowland Technology, Saga City, Japan \\ ${ }^{3}$ Sustainable Management of Natural Resources and Environment Research Group, Faculty of Environment and Labour Safety, \\ Ton Duc Thang University, Ho Chi Minh City, Vietnam \\ Email: doanquangtrikttv@gmail.com
}

How to cite this paper: Thai, T.H. and Tri, D.Q. (2017) Modeling the Effect of Thermal Diffusion Process from Nuclear Power Plants in Vietnam. Energy and Power Engineering, 9, 403-418.

https://doi.org/10.4236/epe.2017.98027

Received: June 1, 2016

Accepted: August 1, 2017

Published: August 4, 2017

Copyright (c) 2017 by authors and Scientific Research Publishing Inc. This work is licensed under the Creative Commons Attribution International License (CC BY 4.0).

http://creativecommons.org/licenses/by/4.0/ (c) (i) Open Access

\begin{abstract}
In this study, we evaluate the ecological impact of effluent cooling water from the Ninh Thuan nuclear power plant II, using a two-dimensional hydraulic model to simulate thermal diffusion from the effluent outfall. Sites selected for this study were Ninh Thuan nuclear power plant and Vinh Hai seawater in four different scenarios. This paper utilized the relationship between surface water temperature and the water temperature at a depth of $-15 \mathrm{~m}$ to calculate the water temperature at intake and outlet at a depth of $-14 \mathrm{~m}$. A combination between the results of interpolated and results of model showed that effluent cooling water from Ninh Thuan plant affected the largest incidence about $2450 \mathrm{~m}$ in the North, $880 \mathrm{~m}$ in the South and $960 \mathrm{~m}$ in the West. It can be considered as safe distance to not to affect the coral reefs ecosystem in the North and sea turtle conservation area in the South. This study was first in this region to have an integrated approach using two-dimensional model.
\end{abstract}

\section{Keywords}

Ninh Thuan Nuclear Power Plant, Effluent Cooling Water, Ecological System, MIKE 21

\section{Introduction}

The increasing global demand for energy has hitherto been met to an increasing extent by the use of fossil fuels and hydropower. Nuclear energy has been developed and used commercially for about two decades to meet a fraction of the electrical energy needs. Statistical data on energy consumption of the world in recent years showed that world consumption has increased by about 
$50 \%$ in less than ten years. Vietnam has considered establishing nuclear power generation since 1995, and firm surfaced proposals in 2006. In July 2014, the government issued a master plan specifying Ninhthuan- I \& II nuclear power plants with a total of capacity $1000 \mathrm{MW}$ e-class reactors [1]. Thermal pollution is the change in the water temperatures of lakes, rivers, and oceans caused by made-man industries or practices. These temperature changes may adversely affect ecosystems by contributing to the decline of wildlife populations and habitat destruction. Any practice that affects the equilibrium of an aquatic environment may alter the temperature of that environment and subsequently cause thermal pollution. Thermal pollution is one parameter of the broader subject of water pollution. The adverse effects of thermal pollution are often conjoined with other forms of water pollution such as chemical contamination or biological contamination [2]. The cooling water discharge from nuclear power plants (NPPs) is among the greatest local sources of thermal pollution due to the high levels of energy produced per plant. In addition, nuclear power plants require $30 \%-100 \%$ more cooling water than other types of plant with a comparable power output [3] [4] [5]. Regulation of thermal pollution has been more elusive than for other forms of water pollution, although straightforward mitigation measures are available, especially in the case of elevated temperature discharges. Some countries and even individual states and provinces require limits on discharges that lead to thermal pollution of receiving waters. This aspect of water pollution has proven to be more elusive than conventional chemical discharge [6] [7] [8]. Numerical models are simplified mathematical representations of physical systems and processes. A numerical model can be constructed as a one-, two-, or three-dimensional model in accordance with the dominant spatial directions of the physical processes [9] [10] [11]. There are several methodologies to study thermal plume behavior, ranging from physical models [12], to in situ data analysis [13] [14] to the use of numerical models [15]. The objectives of this paper were as follows: 1) to simulate the transport of temperature process and thermal diffusion of effluent cooling water of Ninh Thuan nuclear power plant, 2) to impact assessment of effluent cooling water to environment and ecological ecosystem around areas.

\section{Methodology}

\subsection{Description of Study Site}

The Ninh Thuan nuclear power is located in Vinh Hai commune, Ninh Hai district, Ninh Thuan province, far from the center of Ninh Thuan $10 \mathrm{~km}$ in the Southeast of Vietnam (Figure 1). Ninh Thuan plant fits into the buffer zone of Nui Chua National Park, marine protected areas and within a radius of $1 \mathrm{~km}$ inland boundary of the National Park [16]. Ninh Thuan plant is reported on Environmental Impact Assessment (EIA) of the project Ninh Thuan Nuclear Power plant. 




Figure 1. The study location area.

\subsection{Methods}

MIKE 21 FM flow model (HD), a general 2D hydrodynamic modeling system for simulation of flows in estuaries, bays and coastal areas, and in oceans. The MIKE21 FM flow model (HD) solves vertically integrated equations of continuity and momentum in two horizontal dimensions. The discretization in solution domain is performed using a finite volume method. The spatial domain is discretized by subdivision of the continuum into non-overlapping cells [17]. The numerical model Mike 21 solves in two dimensions (in the horizontal plane) stationary/non-stationary flow of incompressible Reynolds averaged Navier-Stokes equations, subject to the assumption of Boussinesq and of a hydrostatic distribution of pressure.

The continuity equation is written as:

$$
\frac{\partial u}{\partial x}+\frac{\partial v}{\partial y}+\frac{\partial \omega}{\partial z}=S
$$

And the two horizontal momentum equations for the $x$ and $y$ component, respectively

$$
\begin{aligned}
& \frac{\partial u}{\partial t}+\frac{\partial u^{2}}{\partial x}+\frac{\partial v u}{\partial y}+\frac{\partial w u}{\partial z} \\
& =f v-g \frac{\partial \eta}{\partial x}-\frac{1}{\rho_{0}} \frac{\partial p_{a}}{\partial x}-\frac{g}{\rho_{0}} \int_{z}^{\eta} \frac{\partial \rho}{\partial x} \mathrm{~d} z+F_{u}+\frac{\partial}{\partial z}\left(v_{t} \frac{\partial u}{\partial z}\right)+u_{s} S
\end{aligned}
$$




$$
\begin{aligned}
& \frac{\partial v}{\partial t}+\frac{\partial v^{2}}{\partial y}+\frac{\partial u v}{\partial x}+\frac{\partial w v}{\partial z} \\
& =f u-g \frac{\partial \eta}{\partial y}-\frac{1}{\rho_{0}} \frac{\partial p_{a}}{\partial y}-\frac{g}{\rho_{0}} \int_{z}^{\eta} \frac{\partial \rho}{\partial y} \mathrm{~d} z+F_{v}+\frac{\partial}{\partial z}\left(v_{t} \frac{\partial v}{\partial z}\right)+v_{s} S
\end{aligned}
$$

where: $t$. time, $u, v, \omega$ : velocities in $x, y, z$ directions, $\eta$ : elevation above mean sea level, $\sigma$ : vertical transformed co-ordinate, $d$ : water depth, $\rho$ : density, $g$. acceleration due to gravity, $f$ : Coriolis parameter, $v_{t}$ : turbulent eddy viscosity, $P_{A}$ : atmospheric pressure, $S:$ the magnitude of the flow due to the point source $u_{s}, v_{s}:$ speed.

$$
\begin{aligned}
& F u=\frac{\partial}{\partial x}\left(2 A \frac{\partial}{\partial x}\right)+\frac{\partial}{\partial y}\left(A\left(\frac{\partial u}{\partial y}+\frac{\partial v}{\partial x}\right)\right) \\
& F v=\frac{\partial}{\partial x}\left(A\left(\frac{\partial u}{\partial y}+\frac{\partial v}{\partial x}\right)\right)+\frac{\partial}{\partial y}\left(2 A \frac{\partial v}{\partial y}\right)
\end{aligned}
$$

where $A$ is a horizontal eddy viscosity; the state of surface and bottom boundary with $u, v$ and $\mathrm{w}$ are calculated as follows:

At $z=\eta$

$$
\frac{\partial \eta}{\partial t}+\frac{\partial \eta}{\partial x}+\frac{\partial \eta}{\partial y}-w=0
$$

At $z=-d$

$$
\begin{gathered}
\frac{\partial d}{\partial x}+v \frac{\partial d}{\partial y}+w=0 \\
\left(\frac{\partial u}{\partial z}, \frac{\partial v}{\partial z}\right)=\frac{1}{\rho_{0} v_{t}}\left(\tau_{b x}, \tau_{b y}\right)
\end{gathered}
$$

where $\left(\tau_{b x}, \tau_{b y}\right)$ are wind surface stress and bottom stress.

The transports of temperature follow the general transport diffusion equation as:

$$
\frac{1}{\rho} \frac{\partial(\rho T)}{\partial t}=\frac{\partial}{\partial x_{j}}\left(\frac{v_{t}}{\sigma_{T}} \frac{\partial T}{\partial x_{j}}\right)+\frac{1}{\rho} Q_{H}
$$

where: $Q_{H}$ is transport of temperature, $\sigma_{T}$ is a number of Prandtl/Schmidt.

\section{Model Setup}

\subsection{Computation Mesh}

The study scope of the factory has sized $5500 \times 10,000 \mathrm{~m}$ with coordinates: Longitude $(1,283,324$ - 1,290,889), Latitude $(604,155$ - 602,341) (Figure 2). The topography and bathymetry data used in the model were provided by survey project from May 23 to June 19, 2014 according to the coordinate system VN 2000 with scale 1:1000. In this paper we used unstructured grid, triangular grid to solve problem (Figure 3(a)). Due to thermal diffusion calculation at intake and outlet area should divide smaller computation grid in this area than the external area to save computation time. The maximum mesh area of the triangular 


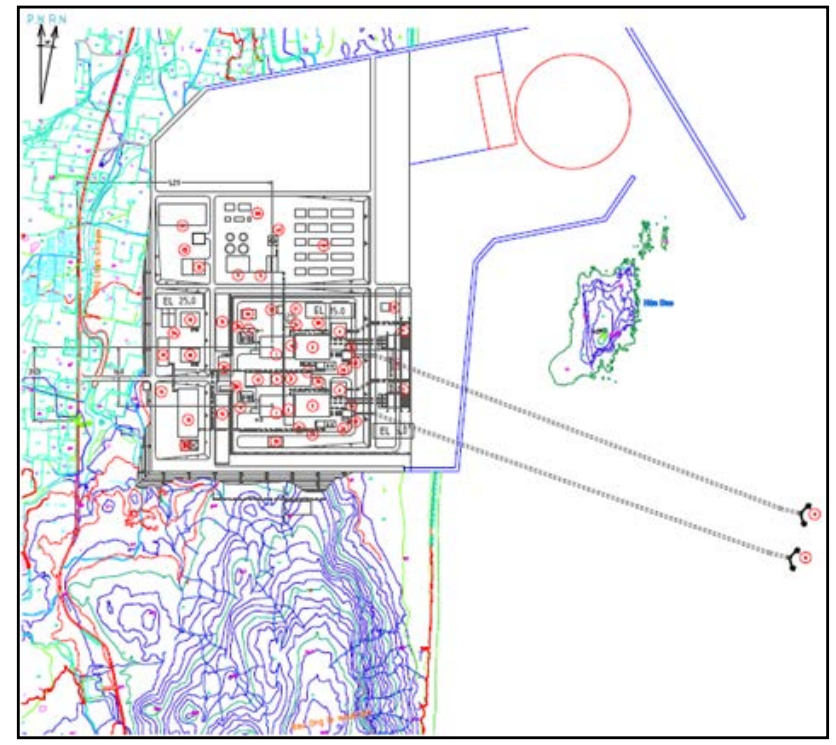

Figure 2. The cross-sectional structure of Ninh Thuan II nuclear power plant.
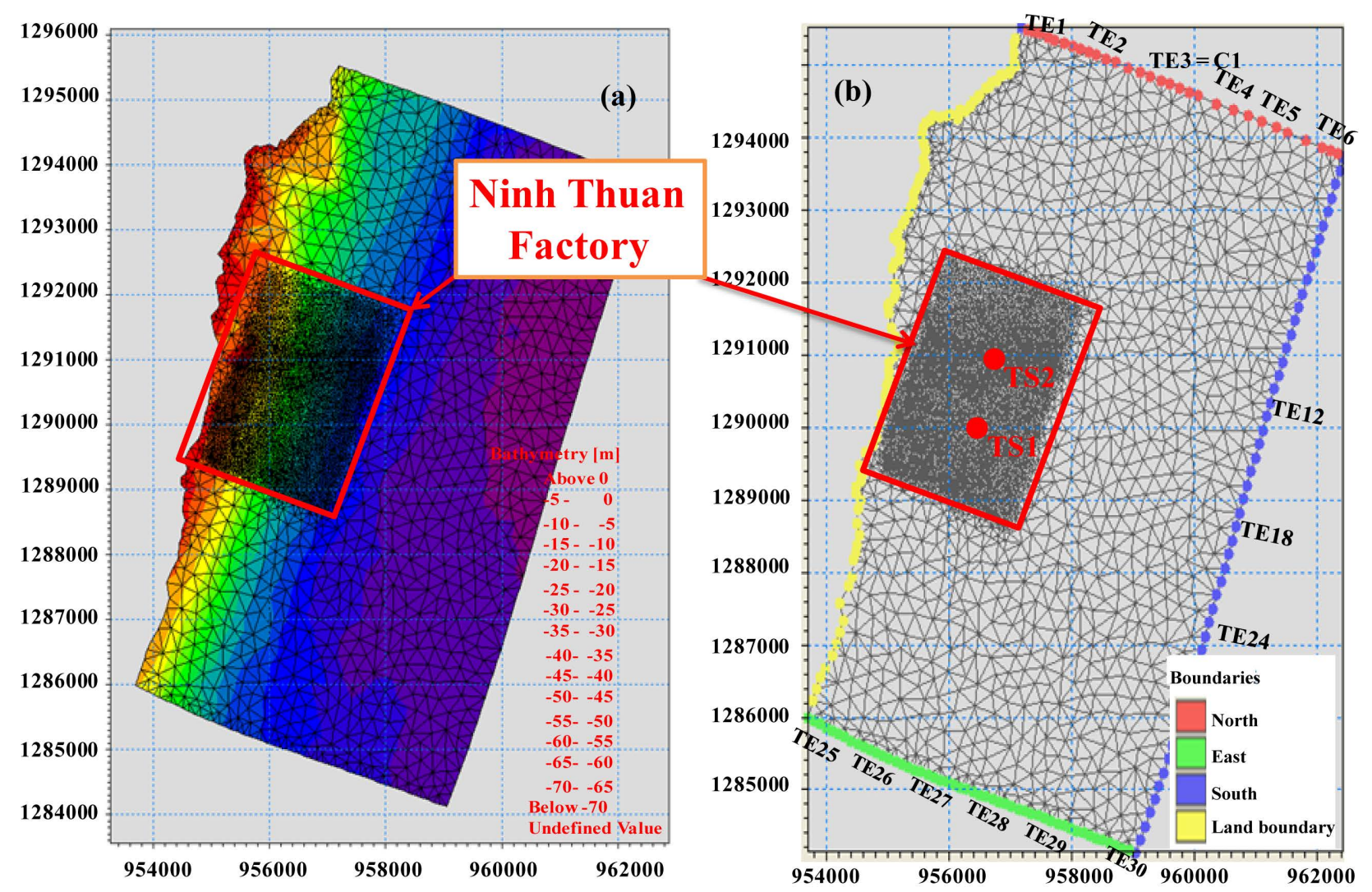

Figure 3. (a) Computation grid-Triangular mesh; (b) Calculated boundaries (C1, TS1 and TS2 are the test positions).

grids is $2000 \mathrm{~m}^{2}$, the sea regional in front of intake effluent cooling water and outlet has sized of $2000 \times 3000 \mathrm{~m}$. The maximum triangular grid of the offshore area can reach to $50,000 \mathrm{~m}^{2}$. The total number of mesh is 11,200 and the number of nodes is 5718 and 4 boundaries including one land boundary, three open 
boundaries in North, East and South (Figure 3(b)).

\subsection{Boundary Condition}

Water level boundary is extracted from the calculation model Dynasty China Sea (Global Forecast System (GFS) of the US National Environment Forecast Center). Temperature boundary used the measure data of the project at the TE1, TE2, TE3, TE4, TE5, TE6 in the northern boundary; TE6, TE12, TE18, TE24, TE30 in the eastern boundary; TE25, TE25, TE27, TE28, TE29, TE30 in the southern boundary in the period from June 2014 to July 2015 (Figure 3(b)). The measured data will be interpolated along the boundary and the chain computation time. Salinity boundary was used from the survey results at a position distance of $1 \mathrm{~km}$ to inland in 2014-2015. The salinity of study area ranged from $32 \%$ - 33\% during rising tide phase. Average salinity has not changed much in years. Average salinity in the dry and rainy season is about 33 ppt. Hence the paper used constant values of salinity in the caculated time series for each season.

\section{Results and Discussion}

\subsection{The Calibration}

The calibration parameters of model are conducted primarily by changes to the hydraulic roughness and diffusion coefficient changes. This paper used measure data at C1 position on June 19-26, 2014 and on December 18-26, 2014 for the water level calibration, on December 18-26, 2014 for the temperature calibration at TS1 and TS2 positions in the model. The results of water level calibration in summer and winter are shown in Figure 4(a) and Figure 4(b). The results of temperature calibration at TS1 and TS2 positions are shown in Figure 4(c) and Figure 4(d). Figure 4(c) and Figure 4(d) showed that the variation tendency of calculated temperature was decreasing at TS1 position from 25.1 to 24.2 degree, at TS2 position from above 25 to 24.1 degree. The results of water level calibration in summer and winter showed a high conformity about phase and water level amplitude between calculated and observed data. By editing Nash-Sutclifee criterion [18] we have the results of water level and temperature calibration (Figure 4). It means that model was edited well with hydraulic parameters. These parameters are used as the basic for validation model and thermal diffusion process.

\subsection{The Validation}

Validation model was used water level data at $\mathrm{C} 1$ position in summer from $\mathrm{Au}$ gust 04-12, 2014 and in winter from December 03-11, 2014. Temperature validation was used observed temperature data at TS1 and TS2 positions from December 03-11, 2014. The results of water level validation at $\mathrm{C} 1$ position in summer and winter are shown in Figure 5(a) and Figure 5(b). The results of temperature validation at TS1 and TS2 position are shown in Figure 5(c) and 


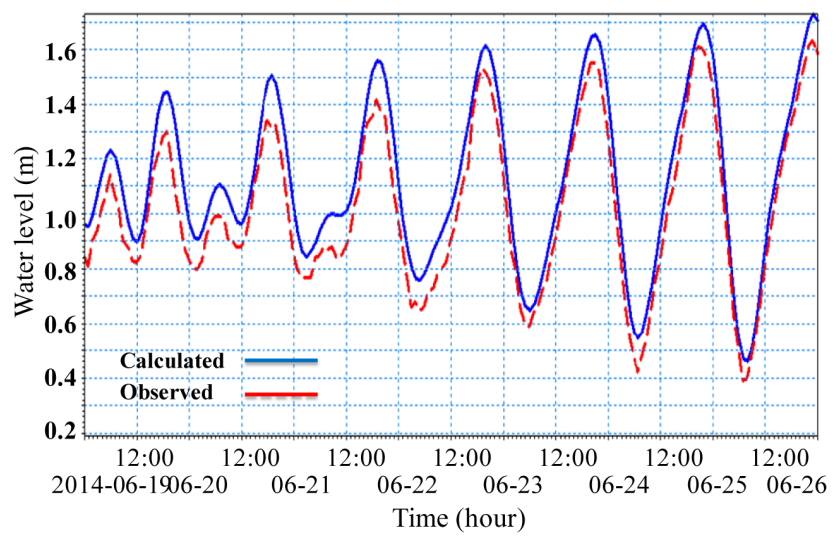

(a)

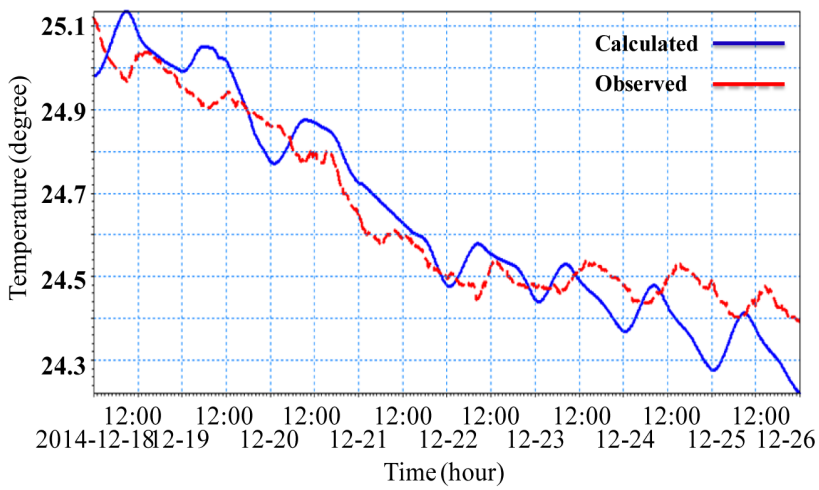

(c)

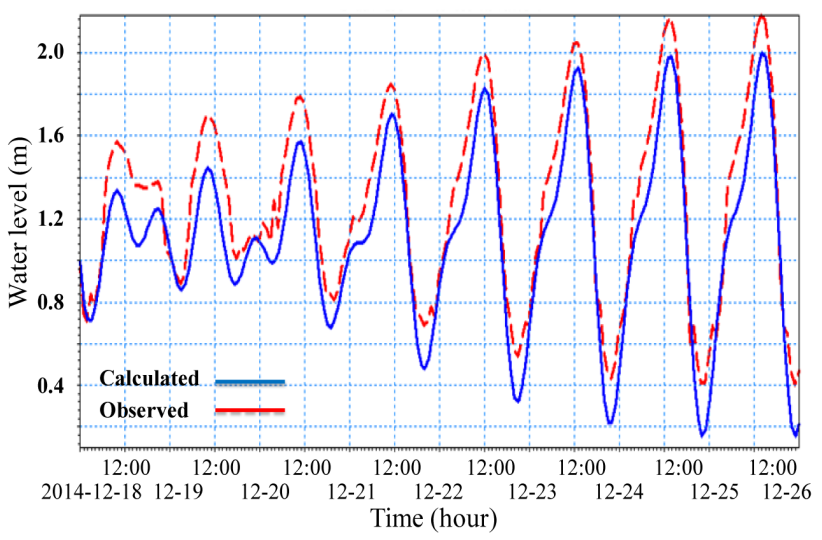

(b)

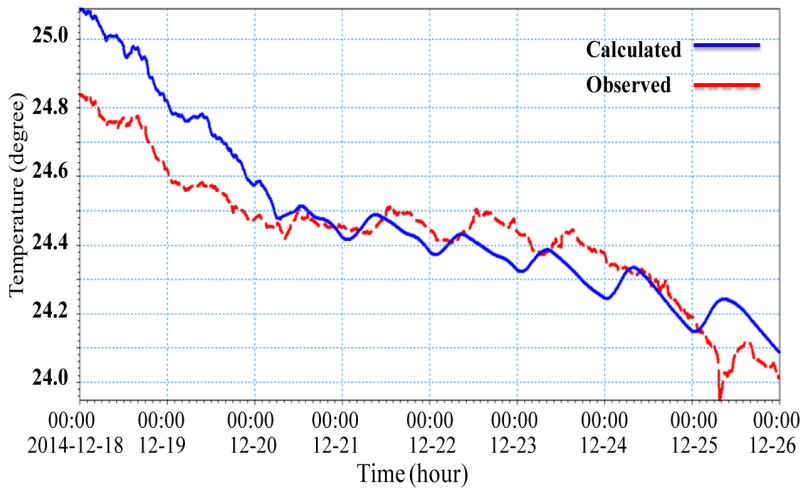

(d)

Figure 4. (a) The calculated and observed of water level calibration at C1 on June 19-26, 2014 with NASH = 0.82; (b) on December 18-26, 2014 with NASH $=0.85$; (c) The calculated and observed of temperature calibration at TS1 position on December 18-26, 2014 with NASH $=0.76$; (d) The calculated and observed of temperature calibration at TS2 position in winter on December $18-26,2014$ with NASH $=0.78$.

Figure 5(d). The variation tendency of temperature validation at TS1 and TS2 positions showed that the simulated temperature involving a tendency was smaller than observed temperature with the maximum peak error about 0.25 degree. The results revealed that in the validation case, the water lever between calculated and observed have a high conformity about phase and water amplitude with Nash-Sutcliffe criterion (Figure 5). The temperature process simulations from calibration and validation model are not really coinciding with the measurement process. The results of calibration and validation showed that the observed line is quite undulating and the simulated line is quite smooth. However, there are quite similar about trajectories. According to analysis above, we can use the parameters in calibration and validation process to apply for the problem of calculating thermal diffusion from effluent cooling water of Ninhthuan-II nuclear power plant in Vinh Hai by using MIKE 21 FM model.

\subsection{Development of Scenarios}

The scenarios were built based on climate characteristics, the computational requirements as follows: 




(a)

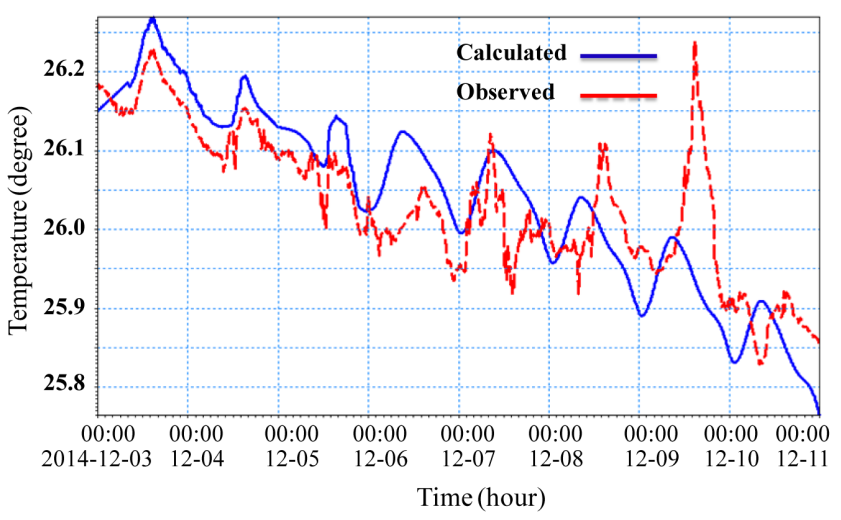

(c)

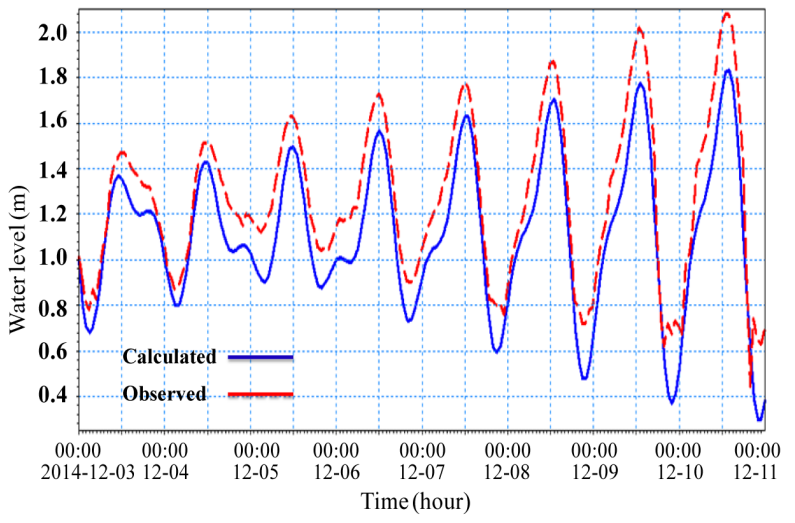

(b)

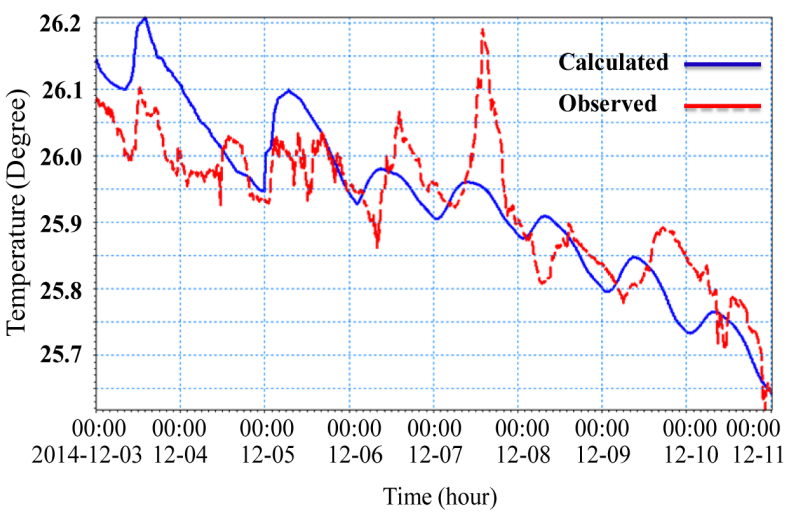

(d)

Figure 5. (a) The calculated and observed of water level validation at $\mathrm{C} 1$ position in summer on August 4-12, 2014 with NASH = 0.84; (b) The calculated and observed of water level validation at C1 position in winter on December 3-11, 2014 with NASH = 0.79; (c) The calculated and observed of temperature validation at TS1 position in winter on December 3-11, 2014 with NASH = 0.72; (d) The calculated and observed of temperature validation at TS2 position in winter on December 3-11, 2014 with NASH $=0.75$.

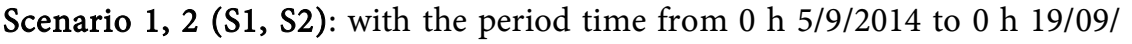
2014 ; regime of rising tide; velocity of flow is $5.1 \mathrm{~m} / \mathrm{s}$; temperature is $28.8^{\circ} \mathrm{C}$; effluent cooling water temperature is $35.8^{\circ} \mathrm{C}$; wind speed is $4.8 \mathrm{~m} / \mathrm{s}$; wind direction is southwest.

Calculation results showed that the changes cycle of water temperature is about 25 hours in the summer. This paper used tidal cycle from 7:00 pm on 8/9/ 2014 to 8:00 pm on 9/9/2014 at falling tide to analyze the temperature's change cycle and determine the greatest impact area.

Calculation results of thermal diffusion by the effluent cooling water at Ninhthuan-II nuclear power plant in scenarios S1, S2 showed that the areas affected by the effluent cooling water is very small; the region has a temperature greater than $1^{\circ} \mathrm{C}$ ambient temperature about $0.114 \mathrm{~km}^{2}$ with distance from the outlet to the south about $880 \mathrm{~m}$ and $290 \mathrm{~m}$ to the west in S1. Scenario S2 with dead tide has an affected area about $0.072 \mathrm{~km}^{2}$ with the distance from the outlet to the North about $920 \mathrm{~m}$ and to the West about $160 \mathrm{~m}$. Initially influenced by the flow, hot water flow moves in southward. When there are southwest winds, ef- 
fluent cooling water gradually move to the Northeast, meet the flow, move closer to the shore and temperature is decreased. A hot flow does not affect to the intake gate of plant. The maximum temperature field in $\mathrm{S} 1$ at 15:00 pm on 8/9/ 2014 is shown in Figure 6(a). The maximum temperature field in S2 at 15:00 pm on 9/9/2014 is shown in Figure 6(b). Finally, effluent thermal flow in two scenarios S1, S2 do not affect effluent cooling water intake area of the plant.

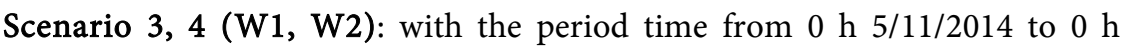
21/11/2014; regime of rising tide; velocity of flow is $5.1 \mathrm{~m} / \mathrm{s}$; temperature is $27.1^{\circ} \mathrm{C}$; effluent cooling water temperature is $34.1^{\circ} \mathrm{C}$; wind speed is $6 \mathrm{~m} / \mathrm{s}$; wind direction is northeast.

Calculation results showed that the changes cycle of water temperature about 25 hours in the summer. This paper used tidal cycle from $23 \mathrm{~h}$ on 12/11/2014 to $0 \mathrm{~h}$ on 14/11/2014 at falling tide to analyze the temperature's change cycle and determine the greatest impact area.

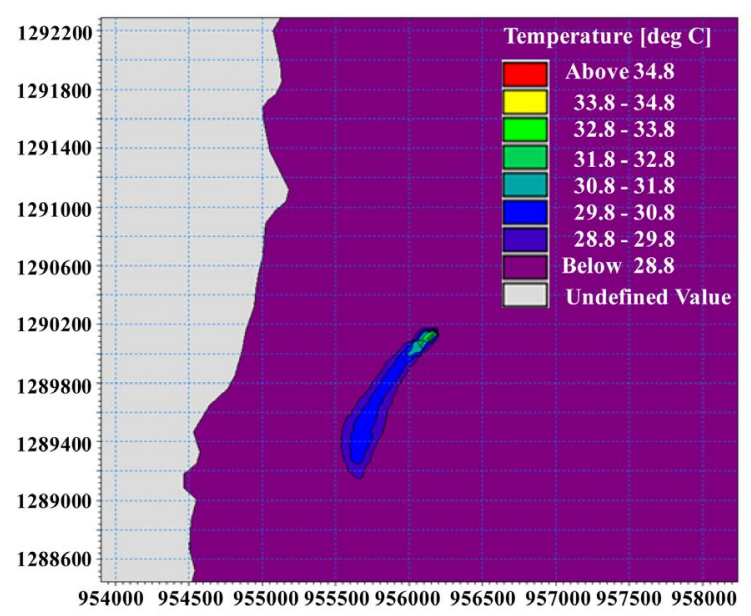

(a)

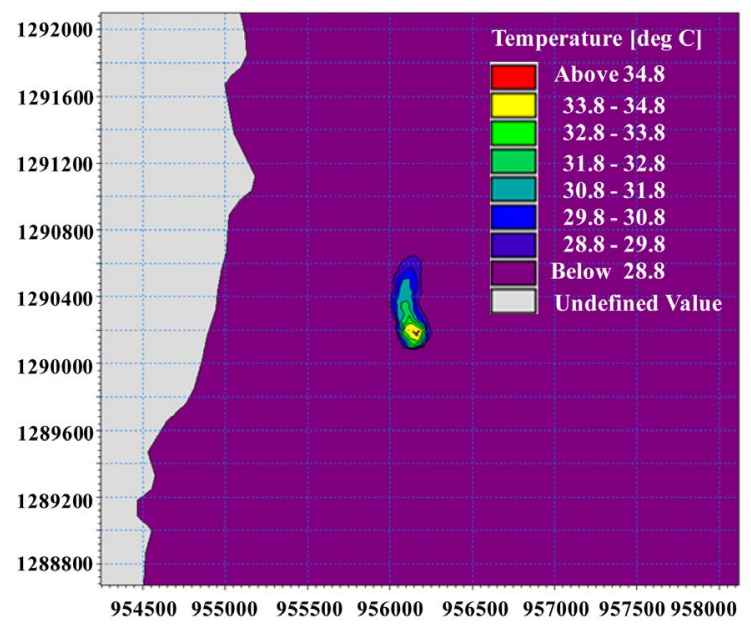

(b)

Figure 6. (a) The maximum temperature field in S1 scenario; (b) The maximum temperature field in $\mathrm{S} 2$ scenario. 
Calculation results of thermal diffusion by the effluent cooling water at Ninhthuan-II nuclear power plant in scenarios W1, W2 showed that the area affected by the effluent cooling water is very small; the region area has a temperature greater than $1^{\circ} \mathrm{C}$ ambient temperature about $1.54 \mathrm{~km}^{2}$ with distance from the outlet to the north about $1950 \mathrm{~m}$ and $550 \mathrm{~m}$ to the west. Scenario W2 with dead tide has an affected area about $1.68 \mathrm{~km}^{2}$ with the distance from the outlet to the North about $2450 \mathrm{~m}$ and to the West about $960 \mathrm{~m}$. Initially influenced by the northeast wind, hot water flow moves in southward. After flow affected by the tide, it moves to Vinhhy bay again. The maximum temperature field in W1 at 2:00 am on 13/11/2014 showed in Figure 7(a). The maximum temperature field in W2 at 19:00 pm on 13/11/2014 showed in Figure 7(b). Finally, effluent thermal flow in two scenarios W1, W2 do not affect the intake effluent cooling water area of the plant.

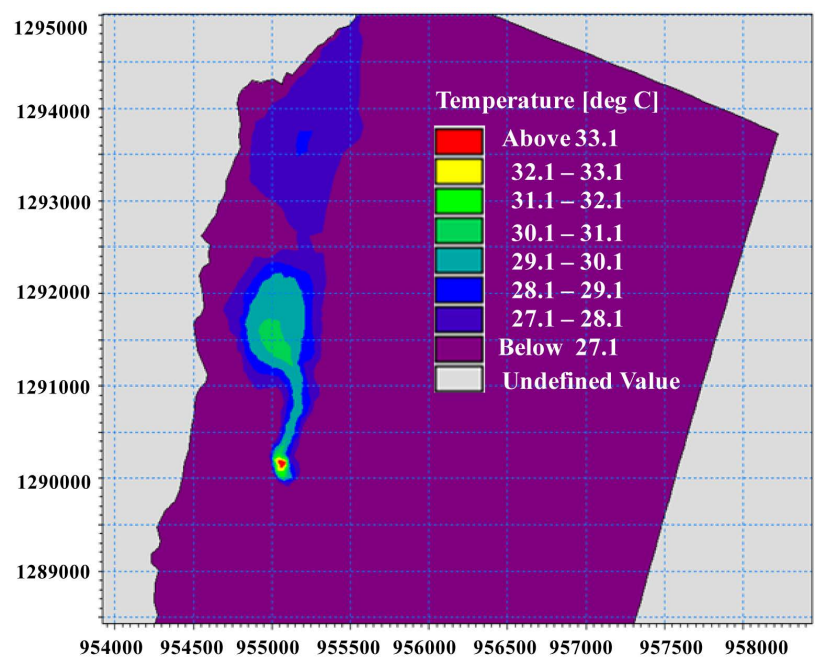

(a)

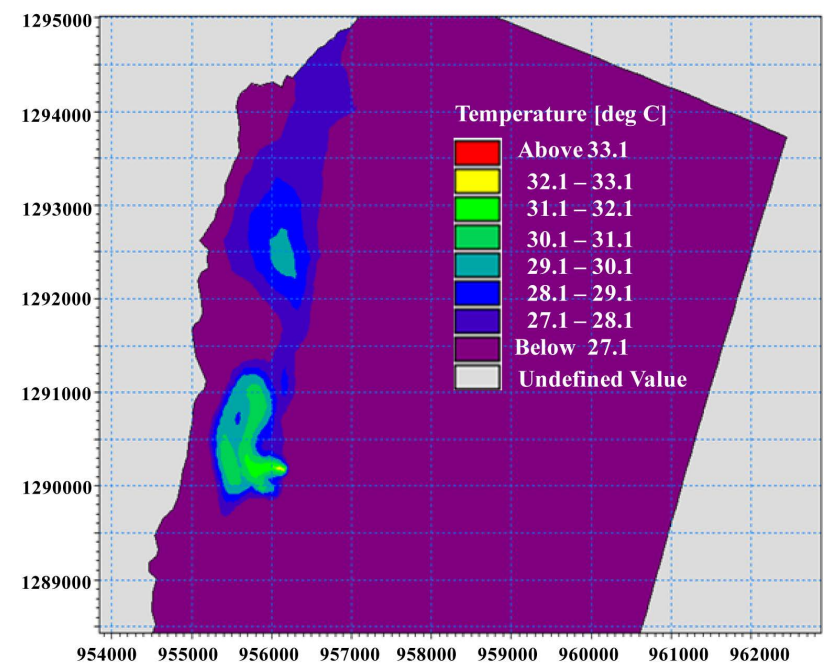

(b)

Figure 7. (a) The maximum temperature field in W1 scenario; (b) The maximum temperature field in $\mathrm{W} 2$ scenario. 


\subsection{Interpolated Calculated Results Follow Depth}

There are not data measuring the depth of water temperature across the study site. This paper used correlation between surface water temperature and water temperature at a depth of $-15 \mathrm{~m}$ at TS1 position to calculate the water temperature at a depth of $-14 \mathrm{~m}$ in placement of intake and outlet of effluent cooling water. Based on the measured data on water temperature at TS1 position on 9/2014, 10/2014-1/2015 and 4-5/2015, we built the relationship between surface water temperature and water temperature at a depth of $-15 \mathrm{~m}$. This relationship lines will be used to interpolate the water temperature at the effluent cooling water outlet location in the above scenarios.

\subsubsection{Application for $\mathrm{S} 1$ and $\mathrm{S} 2$ Scenario}

The scenarios S1, S2 calculated for the period from on September 5-19, 2014. Therefore, we can use the relationship between surface water temperature and water temperature at a depth of $-15 \mathrm{~m}$ measured on September 03, 2011 to interpolate the water temperature at intake and outlet effluent cooling water at a depth of $-14 \mathrm{~m}$ for two scenarios S1 and S2 (Figure 8(a)). Mean square error is 0.743. It represents a good correlation so it can be used for the temperature interpolation process at two positions intake and outlet of effluent cooling water. The results of calculation in Figure 8 showed that in the surface layer and a depth of $-14 \mathrm{~m}$ in the summer thermal of Ninhthuan-II nuclear power plant only ranged from $24.8^{\circ} \mathrm{C}$ to $27.5^{\circ} \mathrm{C}$ at the intake and $23.8^{\circ} \mathrm{C}-26.8^{\circ} \mathrm{C}$ at the outlet. It does not affect the taking effluent cooling water of plant.

\subsubsection{Application for $\mathrm{W} 1$ and $W 2$ Scenario}

The scenarios W1, W2 calculated for the period on November 5-21, 2014. Therefore, we can use the relationship between surface water temperature and water temperature at a depth of $-15 \mathrm{~m}$ measured on October 9, 2014 to November 15, 2015 to interpolate the water temperature at intake and outlet effluent cooling water at a depth of $-14 \mathrm{~m}$ for two scenarios W1 and W2 (Figure 8(b)). Mean square error is 0.983 . It indicates a very good correlation so it can be used for the temperature interpolation process at two positions intake and outlet of effluent cooling water in above two scenarios W1, W2. The results of calculation showed that the surface layer and a depth layer of $-14 \mathrm{~m}$ in the summer thermal of Ninhthuan-II nuclear power plant only ranged from $25.8^{\circ} \mathrm{C}$ to $26.5^{\circ} \mathrm{C}$ at the intake and $25.7^{\circ} \mathrm{C}-27.3^{\circ} \mathrm{C}$ at the outlet. It does not affect the taking effluent cooling water of factory.

\subsection{Impact Assessment of Effluent Cooling Water on Environmental and Ecological System}

It is now generally acknowledged that coral reefs are among the most threatened global ecosystems, and among the most vital [19] [20] [21] [22] [23]. Reefs are of critical importance to human survival because they provide subsistence food for a substantial portion of the population, serve as the principle coastal protection 


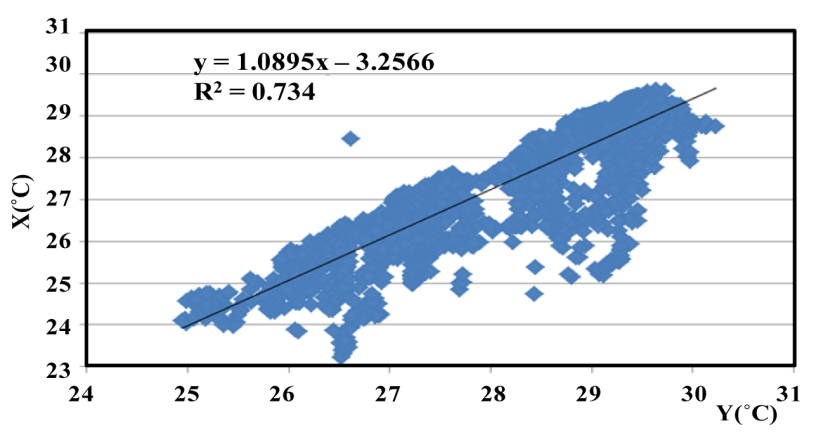

(a)

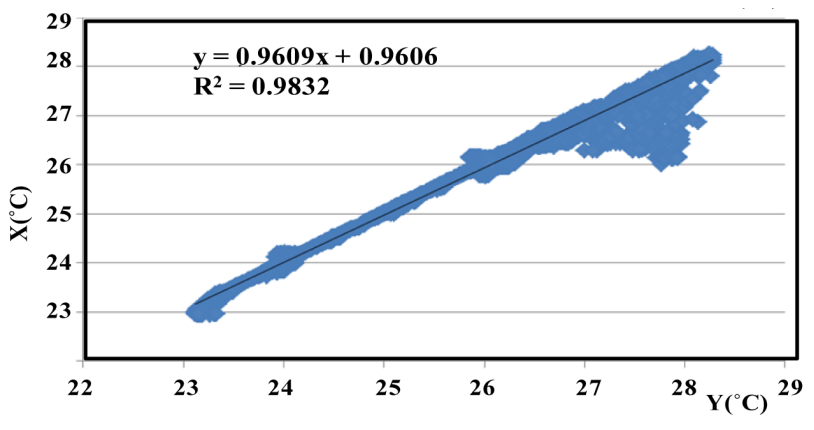

(b)

Figure 8. (a) Correlation between surface water temperature and water temperature at a depth layer of $-15 \mathrm{~m}$ on September 2011; (b) Correlation between surface water temperature and water temperature at a depth layer of $-15 \mathrm{~m}$ on November 2011 to January 2012.

structures for most tropical islands, and contribute major income and foreign exchange earnings from tourism [24] [25]. The field survey in this place the most notable is the coral reefs in Thai An about 200 ha wide area. Outside the region has a sand and coral (65\% sand, $35 \%$ coral), inside region is the dead coral areas account for $60 \%, 40 \%$ living coral. Oviparity of turtle beaches concentrated in the northern of the plant from Mong Tay to Ngang beach and sea turtle conservation concentrated in the southern (Figure 9).

The condition of marine life depends on: water level and water level fluctuations, flow rate, water clarity, salinity, etc. In fact, biological living in the water affected by many environmental factors such as: light, temperature, $\mathrm{pH}$, dissolved oxygen, $\mathrm{CO}_{2}$, etc. The environmental factors impact on the organism living referred to as the ecological factors. Each organism can only withstand the impact of a certain limit of a factor, called ecological limitation. Each species has own ecological threshold so they are distributed in the areas of climate (temperature) characteristics. The distribution is often limited by the condition above and below the range polarization lead to decrease of growth and reproductive or increase mortality level of the species. Water temperature conditions outside the range polarization usually have a relationship with other factors (humidity, dissolved oxygen concentration, the solubility of the substance, etc.); create the aggregate impact on the organisms. 


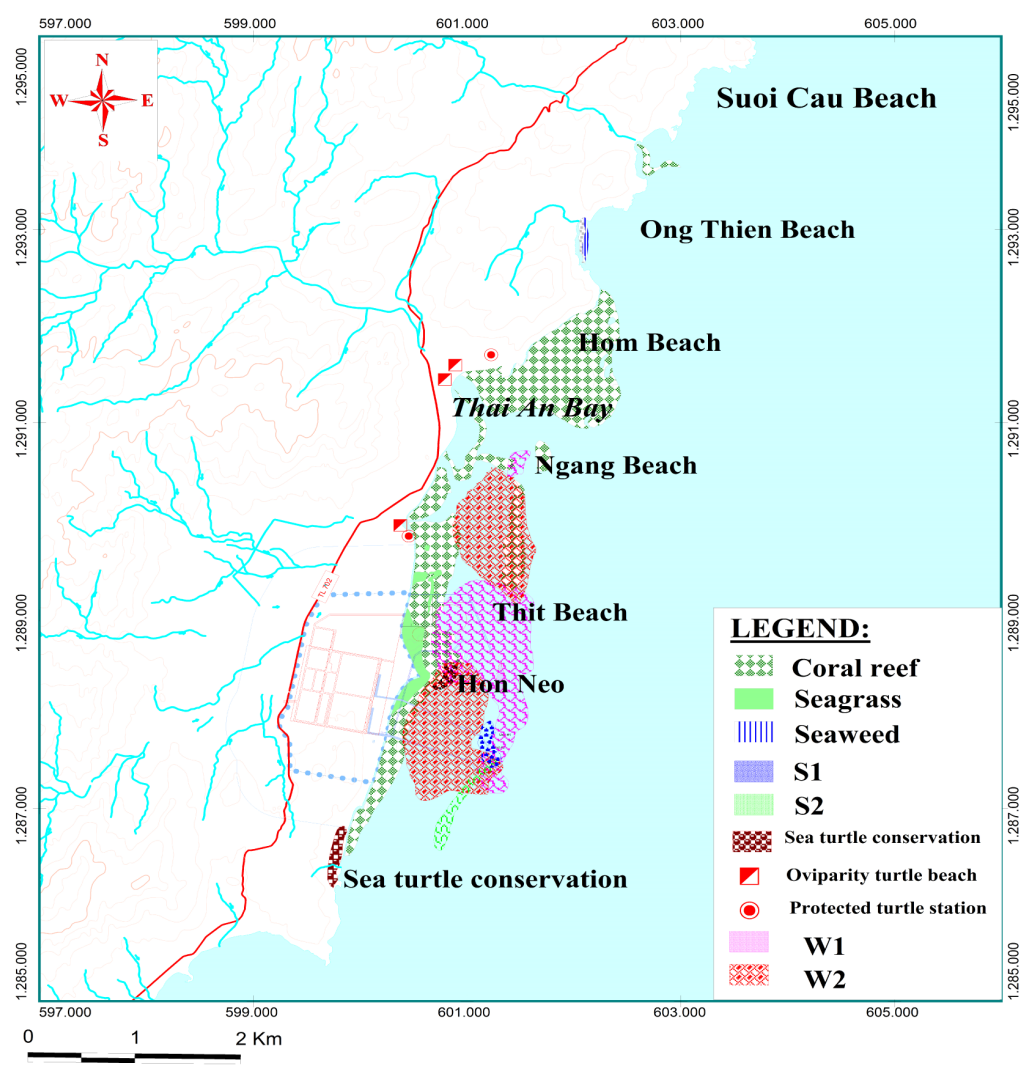

Figure 9. A combination map between ecosystem and results of model.

According to the biological characteristics of coral reefs temperature for normal development is about $20^{\circ} \mathrm{C}-32^{\circ} \mathrm{C}$. When the water temperature is higher than $2^{\circ} \mathrm{C}$, over $29^{\circ} \mathrm{C}$ exceeding $1-2$ weeks, corals will start exhausted and dead. The sex of sea turtles depends greatly on the environmental temperature. Specifically, when the high around environmental temperature sea turtle eggs will be hatched females, while low temperature will be hatched males. If the ambient temperature increased about $4^{\circ} \mathrm{C}$, all eggs will be hatched females. This gender will be imbalance and lead to the extinction of sea turtles species. The simulation results of the scenarios showed that the effluent thermal water from Ninhthuan-II nuclear power plant has the trajectories moving to North and it does not affect the intake gate and sea turtle beach. Area of higher temperature $1^{\circ} \mathrm{C}$ is quite small, non-pollution thermal for the study area. According to the National Technical Regulation on industrial wastewater quality NTR 40:2011/MONRE, the maximum limitation value allow of the industrial wastewater temperature is $40^{\circ} \mathrm{C}$. Finally, the impact of cooling water discharges of Ninh Thuan-II nuclear power plant does not affect large environment and within the permissible limits. The results of the thermal diffusion simulation combined the model and ecosystem maps give us an overview of the impact to the Ninh Thuan ecosystem.

\section{Conclusion}

The affected areas by the effluent cooling water in four simulation scenarios are 
very small, ranging about $0.072-1.68 \mathrm{~km}^{2}$, the largest incidence about $2450 \mathrm{~m}$ in the North, $880 \mathrm{~m}$ in the South, $960 \mathrm{~m}$ in the West. It does not affect the intake gate of plant. In addition, this paper also builds the relationships between surface water temperature and the water temperature at a depth of $-15 \mathrm{~m}$ to calculate the water temperature at intake and outlet at a depth of $-14 \mathrm{~m}$. The combination between this results and results of MIKE 21 FM model can assess the magnitude of effluent cooling water to the environmental and marine ecosystem. The influence area and temperature of effluent cooling water do not affect the coral reefs area in the North and sea turtle conservation in the southern of the plant.

\section{Acknowledgements}

We are grateful to thank Le Hoang Anh, Trinh Hoang Long and Ha Trong Ngoc for their assistance with the collection of land use, topography, meteorological, salinity, temperature and oceanographic data. We are thankful to Institute of Energy Consulting for Thermal, Nuclear Power and Environment for this research opportunity and for the facilities that were used to perform the study.

\section{References}

[1] Le, D.P. (2011) Vietnam's Nuclear Power Development Plan: Challenges and Preparation Work for the First Nuclear Power Projects. https://www.iaea.org/INPRO/3rd_Dialogue_Forum/20.LeDoanPhac-Vietnam.pdf

[2] Andrew, G. (2005) The Human Impact on the Natural Environment: Past, Present, and Future. Wiley Publishing, 376.

http://as.wiley.com/WileyCDA/WileyTitle/productCd-140512704X.html

[3] Davidson, B. and Bradshaw, R.W. (1967) Thermal Pollution of Water Systems. Environmental Science Technology, 1, 618-630. https://doi.org/10.1021/es60008a606

[4] Cairns, J. (1971) Thermal Pollution: A Cause for Concern. Journal of the Water Pollution Control Federation, 43, 55-66.

[5] Electric Power Research Institute (EPRI) (2008) Water Use for Electric Power Generation. EPRI, Palo Alto, 1014026.

http://www.epri.com/abstracts/Pages/ProductAbstract.aspx?ProductId $=0000000000$ $\underline{01014026}$

[6] John, H.D. (1979) Limited Liability for Nuclear Accidents: Duke Power Co. v. Carolina Environmental Study Group. Ecology Law Quarterly, 8, 163-185.

http://scholarship.law.berkeley.edu/elq/vol8/iss1/4/

[7] Robert, L.A. (2002) Environmental Law for Engineers and Geoscientists (Ed.), Lewis Publishers, Boca Raton, FL. Journal of Hazardous Materials, 93, 255-256.

[8] National Academy of Engineering and National Research Council (2004) Urbanization, Energy, and Air Pollution in China: The Challenges Ahead-Proceedings of a Symposium. The National Academies Press, Washington DC.

https://doi.org/10.17226/11192

[9] Abbaspour, M., Javid, A.H., Moghimi, P. and Kayhan, K. (2005) Modeling of Thermal Pollution in Coastal Area and Its Economical and Environmental Assessment. International Journal of Environmental Science and Technology, 2, 13-26. http://link.springer.com/article/10.1007\%2FBF03325853 https://doi.org/10.1007/BF03325853 
[10] Lowe, S.A., Schuepfer, F. and Dunning, D.J. (2009) Case Study: Three-Dimensional Hydrodynamic Model of a Power Plant Thermal Discharge. Journal of Hydraulic Engineering, 135, 247-256. https://projecteuclid.org/euclid.jam/1314650245 https://doi.org/10.1061/(ASCE)0733-9429(2009)135:4(247)

[11] Kim, D.G. and Cho, H.Y. (2006) Modeling the Buoyant Flow of Heated Water Discharged from Surface and Submerged Side Outfalls in Shallow and Deep Water with a Cross Flow. Environmental Fluid Mechanics, 6, 501-518.

http://link.springer.com/article/10.1007\%2Fs10652-006-9006-3

https://doi.org/10.1007/s10652-006-9006-3

[12] El-Ghorab, E.A.S. (2013) Physical Model to Investigate the Effect of the Thermal Discharge on the Mixing Zone (Case Study: North Giza Power Plant, Egypt). Alexandria Engineering Journal, 52, 175-185.

[13] Jan, S., Chen, C.T.A., Tu, Y.Y. and Tsai, H.S. (2004) Physical Properties of Thermal Plumes from a Nuclear Power Plant in the Southernmost Taiwan. Journal of Marine Science and Technology, 12, 433-441. http://jmst.ntou.edu.tw/marine/12-5/433-441.pdf

[14] Hunt, C.D., Mansfield, A.D., Mickelson, M.J., Albro, C.S., Geyer, W.R. and Roberts, P.J. (2010) Plume Tracking and Dilution of Effluent from the Boston Sewage Outfall. Marine Environmental Research, 70, 150-161.

[15] Bedri, Z., Bruen, M., Dowley, A. and Masterson, B. (2013) Environmental Consequences of a Power Plant Shut-Down: A Three Dimensional Water Quality Model of Dublin Bay. Marine Pollution Bulletin, 71, 117-128.

[16] Vu, T.T.N. (2012) Evaluating the Effectiveness of Co-Management in Nui Chua National Park Marine Protected Area Ninh Thuan Province, Vietnam. Ms. Thesis, The Norwegian College of Fighery Science University of Tromso, Norway \& Nha Trang University, Vietnam. http://munin.uit.no/bitstream/handle/10037/4751/thesis.pdf?sequence=2

[17] (2007) MIKE 21 Flow Model User Guide and Scientific Documentation. Danish Hydraulic Institute, 3-27. http://aidea.org/...Models/.../MIKE_21/MIKE_FM_HD_2D.pdf

[18] Nash, J.E. and Sutcliffe, J.V. (1970) River Flow Forecasting through Conceptual Models Part I-A Discussion of Principles. Journal of Hydrology, 10, 282-290.

[19] Costanza, R., d'Arge, R., de, G.R., Farber, S., Grasso, M., Hannon, B., Limburg, K., Naeem, S., O’Neill, R. and Paruelo, J. (1997) The Value of the World's Ecosystem Services and Natural Capital. Nature, 387, 253-260.

http://www.nature.com/nature/journal/v387/n6630/abs/387253a0.html?foxtrotcallb ack=true

[20] Bryant, D., Burke, L., McManus, J. and Spalding, M. (1998) Reefs at Risk: A Map-Based Indicator of Threats to the World's Coral Reefs. World Resources Institute, Washington DC. http://www.wri.org/publication/reefs-risk

[21] Boesch, D.F., Field, J.C. and Scavia, D. (2000) The Potential Consequences of Climate Variability and Change on Coastal Areas and Marine Resources: Report of the Coastal Areas and Marine Resources Sector Team, U.S. National Assessment of the Potential Consequences of Climate Variability and Change. Coastal Ocean Program Decision Analysis Series 21. U.S. Global Change Research Program, National Oceanic and Atmospheric Administration, Silver Springs, Maryland. http://www.graham.umich.edu/scavia/wp-content/uploads/2009/11/noaa_climate_i mpacts_das_report.pdf

[22] Reaser, J.K., Pomerance, R. and Thomas, P.O. (2000) Coral Bleaching and Global 
Climate Change: Scientific Findings and Policy Recommendations. Conservation Biology, 14, 1500-1511.

http://www.jstor.org/stable/2641802?seq=1\#page_scan_tab_contents https://doi.org/10.1046/j.1523-1739.2000.99145.x

[23] Wilkinson, C. (2000) Status of Coral Reefs of the World. Australian Institute of Marine Science, Cape Ferguson.

http://www.icriforum.org/sites/default/files/gcrmn2000.pdf

[24] Wells, S., West, J., Westmacott, S. and Teleki, K. (2001) Management of Bleached and Severely Damaged Coral Reefs. In: Schuttenberg, H.Z., Ed., Coral Bleaching: Causes, Consequences, and Response, Coastal Management Report 2230, Coastal Resources Center, Narragansett, 73-80.

http://www.crc.uri.edu/download/COR_0011.pdf

[25] Salm, R.V., Smith, S.E. and Llewellyn, G. (2001) Mitigating the Impact of Coral Bleaching through Marine Protected Area Design. In: Schuttenberg, H.Z., Ed., Coral Bleaching: Causes, Consequences, and Response, Coastal Management Report 2230, Coastal Resources Center, Narragansett, 81-88.

\section{Submit or recommend next manuscript to SCIRP and we will provide best} service for you:

Accepting pre-submission inquiries through Email, Facebook, LinkedIn, Twitter, etc. A wide selection of journals (inclusive of 9 subjects, more than 200 journals)

Providing 24-hour high-quality service

User-friendly online submission system

Fair and swift peer-review system

Efficient typesetting and proofreading procedure

Display of the result of downloads and visits, as well as the number of cited articles

Maximum dissemination of your research work

Submit your manuscript at: http://papersubmission.scirp.org/

Or contact epe@scirp.org 